\title{
REVIEW
}

Open Access

\section{Esthetic, mechanical, and biological outcomes of various implant abutments for single-tooth replacement in the anterior region: a systematic review of the literature}

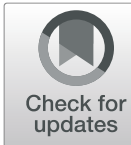

Dimitra Totou', Olga Naka ${ }^{1,2^{*}}$ (D), Shamir B. Mehta ${ }^{1}$ and Subir Banerji ${ }^{1}$

\begin{abstract}
Background: The choice of the appropriate implant abutment is a critical step for a successful outcome. Titanium abutments have demonstrated high survival rates, due to their excellent biocompatibility and high mechanical strength, although they often result in a grayish discoloration of the peri-implant mucosa. This esthetic concern culminated in the introduction of ceramic abutments. The aim of this review was to assess the esthetic, mechanical, and biological outcomes as well as the survival of the different types of abutments used for single-implant restorations in the anterior area.

Material and methods: An electronic search was conducted in Medline, Embase, and Cochrane Central databases using the appropriate Mesh terms and predetermined eligibility criteria. The quality of the studies was assessed using the ROB 2 tool. The last search was conducted on 18th of March 2020.

Results: From the 2074 records initially identified, 23 randomized controlled trials (32 publications) were included for qualitative analysis. Data were classified based on study information, specific characteristics of the intervention and comparator, and information related to the outcome measures. Seven studies exhibited an overall low risk of bias, while twelve studies raised some concerns.

Conclusions: The rate of abutment failure was low and was associated with the ceramic abutments, especially those with internal connection. Limited correlation was noted between soft tissue thickness and color difference. Titanium abutments caused significantly more discoloration to the soft tissues than ceramic abutments, while hueing (gold or pink) slightly improved their color performance. Zirconia allowed a better color match than titanium or gold abutments, still discolored slightly the soft tissues. The submucosally modified zirconia abutments exhibited encouraging results. No significant difference was reported between materials or different types of retention on recession, papillary fill, and biological outcomes.
\end{abstract}

Keywords: Implant abutment, Zirconia abutment, Single-implant restoration, Esthetics, Anterior implants

\footnotetext{
* Correspondence: naka@dent.auth.gr

${ }^{1}$ Faculty of Dentistry Oral and Craniofacial Sciences, King's College London, London, UK

${ }^{2}$ School of Dentistry, Aristotle University of Thessaloniki, 54124 Thessaloniki, Greece
} 


\section{Background}

Dental implant placement for a single anterior tooth rehabilitation is shown to have high survival rates [1]. The criteria for implant survival over time, include the biological integration of the implant, the absence of mechanical complications, and the esthetic integration of the restoration with the adjacent teeth $[2,3]$. The latter parameter is multifactorial. The gingival margin levels, the interproximal papilla, the soft tissue contour, the color of the tissues, the color, anatomy, and texture of the restoration should mimic those of the adjacent natural teeth $[4,5]$.

The choice of the appropriate implant abutment is a critical step for a successful outcome. Titanium abutments have demonstrated high survival rates [6-8], due to their excellent biocompatibility and high mechanical strength [9]. Nevertheless, metallic abutments often result in a grayish discoloration of the peri-implant mucosa, especially in thin biotype soft tissues [10-13].

This esthetic concern culminated in the introduction of ceramic abutments. However, the early designs of ceramic abutment manufactured from densely sintered alumina were associated with an increased risk of fracture $[14,15]$. Yttrium-stabilized zirconia for CAD-CAM abutments on the other hand have exhibited increased mechanical strength compared to alumina, and excellent biocompatibility comparable to that of titanium [16-19]. However, zirconia has been associated with lower fracture resistance than titanium [20, 21], as it is a more brittle material. Systematic reviews comparing ceramic with metal abutments have shown no significant difference in the technical complication rates or the survival rates $[7,8]$. Notably, these systematic reviews assessed abutments in both anterior and posterior areas, supporting both single-implant restorations and fixed partial dentures, and included mainly abutments with an external connection. Evidence suggests that even zirconia abutments fail to completely integrate with the natural teeth due to their bright white color which can result in blanching of the peri-implant mucosa [22]. Therefore, a novel concept of modifying the zirconia abutments, either by using a fluorescent zirconia material or by veneering the submucosal part of the abutment with pink or fluorescent porcelain has been introduced [23, 24].

There is a plethora of current research on the esthetics of anterior single-implant restorations; however, the interpretation of the data can be confusing due to the heterogenicity of the studies. There are systematic reviews based exclusively on assessing the treatment outcomes of zirconia abutments, while the metallic abutments have not been addressed $[25,26]$. Moreover, the review question of some systematic reviews focused not only on single implants in the anterior area but also in the posterior area $[25,27]$. As the mechanical and esthetic requirements of implant restorations in the anterior and posterior regions are not identical, their combination can lead to erroneous interpretations of the results. Furthermore, the eligibility criteria of some reviews included evidence from case reports and case series to reach their conclusions, which are low in the hierarchy of evidence [28]. The most recent systematic review comparing the esthetic, mechanical, and biological outcomes of various implant abutment designs in the anterior region was conducted by Bidra et al. in 2013 [29]. However, in the last 7 years, new advances in implant dentistry have resulted in the introduction of new evidence as well as the introduction of contemporary abutment materials and abutment configurations.

Thus, the aim of this systematic review was to review the up to date evidence and assess the esthetic, biological, and mechanical outcomes alongside the survival of the different types of abutments used for singleimplant restorations in the anterior region. The objectives of the study were to identify and assess the effect of each type of implant abutment on specific esthetic parameters relating to pink and white esthetics, biological parameters, mechanical complications, and the different modes of failure.

\section{Material and methods}

This systematic review was conducted following the PRISMA statement for reporting systematic reviews [30]. A protocol for this review was agreed beforehand and was registered in PROSPERO (CRD42020204083).

The PICO (Population, Intervention, Comparison, Outcome) criteria framed the following research question: In adults restored with single-implant abutment in the upper and/or lower anterior zone (first bicuspid to first bicuspid), which implant abutment (zirconia; alumina; titanium; cast metal abutment) performs best in terms of esthetic, mechanical, biological and survival outcomes?

\section{Eligibility criteria}

The studies included had to be randomized clinical trials, published in peer reviewed journals in English language. The full text of the studies had to be retrievable. Non-randomized clinical studies, observational clinical studies, case reports, case series, in vitro studies, and studies related to implant abutments for a provisional restoration were excluded.

\section{Search strategy}

Studies were identified through electronic search of the Ovid Medline, Embase, and Cochrane Central Register of Controlled Trials (CENTRAL) databases. Moreover, the references of included articles were hand-searched for relevant studies. All databases were searched with no 
time filter. The following combination of keywords was used: ("single implant in the aesthetic zone" OR "single tooth replacement" OR "single dental implant" OR "single-implant reconstruction" OR "dental implants, singletooth" [MeSh term] OR "single-implant crown" OR "single-tooth implant" OR "implant-supported crowns" OR "dental prosthesis, implant-supported" [MeSh term]) AND ("implant abutment" OR "zirconia abutment" OR zirconium [Mesh term] OR "titanium abutment" OR "alumina abutment" OR "ceramic abutment" OR "esthetic abutment" OR "CAD-CAM abutment" OR "dental abutments" [MeSh term] OR "custom abutment" OR "dental implant-abutment design" [MeSh term] OR "gold-alloy abutment" OR "titanium base" OR "individualized abutment" OR "alumina-toughened zirconia abutment") AND ("survival rate" [MeSh term] OR "success rate" OR "survival analysis" [MeSh term] OR "mechanical outcomes" OR "technical outcomes" OR "biological outcomes" OR "clinical outcomes" OR "clinical performance" OR "esthetic outcomes" OR "esthetic performance" OR "esthetics, dental" [MeSh term] OR "technical complication" OR "biological complication" OR "retention" OR "screw loosening" OR "screw fracture" OR "fracture" OR "chipping" OR "spectrophotometric analysis" OR "discoloration" OR "color change" OR "periimplant soft tissue" OR "peri-implant mucosa" OR "soft tissue reaction" OR "dental prosthesis repair" [MeSh term] OR "dental restoration failure" [MeSh term]).

The last database search was conducted on 18th of March 2020.

The study selection process was performed by two independent reviewers, reducing the possibility of rejecting relevant reports. Any disagreements were resolved debating with the other authors.

Data were classified based on study information, specific characteristics of the intervention and comparator, and information related to the outcome measures. Articles with the same sample were summarized as one study. In cases where the same research team had multiple publications of the same trial, the most recent one was included, unless a previous publication had different sample size. When several publications of the same project reported different outcomes, the relevant data were extracted and presented in the most recent publication.

The findings of the individual studies were combined to reveal similarities and differences across the primary studies. The methods used to generate the research question were grouped as well as the outcomes, where possible quantitative synthesis was performed. Where the included studies were heterogeneous mainly in terms of design and methodology, qualitative interpretation of the results was performed.

The quality of the included studies was assessed using the Cochrane Risk of Bias tool (ROB 2) [31].

\section{Results}

\section{Study selection}

The study selection process is illustrated in Fig. 1. Fortyseven articles were assessed for eligibility through fulltext reading while 15 of them were excluded with reasons, as described in Table 1 [32-46]. Moreover, 9 articles were publications of the same clinical trial, but had a different sample size or outcomes (Table 2). Therefore, 23 studies (32 publications) were included in this systematic review.

All studies included abutments placed in the anterior maxilla and 9 of them reported implants placed in the anterior mandible (Table 3). Regarding the abutment material type, 7 studies reported outcomes of zirconia (Zr) abutments [50, 53, 57, 59, 69, 72, 73], 6 studies compared zirconia with titanium (Ti) and other metal abutments (2 Zr vs Ti [67, 68], $1 \mathrm{Zr}$ vs gold alloy [66], 3 $\mathrm{Zr}$ vs pink $\mathrm{Ti} / \mathrm{Ti} /$ gold $\mathrm{Ti}[22,70,71]), 3$ studies compared alumina with metallic abutments (2 with $\mathrm{Ti}[13$, 15], 1 with gold [51]) and 3 studies compared different titanium abutments (2 compared abutment macrodesign [60,74] and 1 abutment color; pink vs conventional gray [65]). Both prefabricated [15, 50, 51, 57-61, 73 ] and customized [12, 21, 22, 46-49, 52-56, 62-68, 70-72] abutments were used.

Most ceramic abutments were restored with allceramic cemented $[13,15,22,50,53,57,65,67,69-71$, 73 ] or screw retained $[13,15,51,53,57,59,69,72,73]$ crowns. The metallic abutments were restored with either cemented $[13,15,60,66,68,74]$ or screw retained $[13,51]$ metal-ceramic (PFM) crowns.

\section{Mechanical outcomes}

Eleven studies (14 articles) explored the mechanical parameters of the abutments (Table 4). Only 6 of these studies reported zirconia or alumina abutment fracture $[15,50,53,57,67,73]$. Nineteen abutments fractured from a total of 446 while 5 fractured at the time of placement during tightening or at the laboratory procedures [15]. Notably, no fractures were reported in the metallic abutments. The fracture rate varied between 3 and $14 \%$. Most fractures were assessed in internally connected ceramic customized abutments. Screw loosening was considered a minor complication and was reported only in 2 studies of zirconia abutments at a rate of $6 \%$ $[49,73]$. Complications of the crowns supported by the abutments were also reported. The minor chipping of the veneering ceramic was the most common complication $[50,51,54,57,66,73]$. Only 4 studies reported major fracture of the ceramic (all-ceramic restorations) that required crown replacement $[15,53,58,69]$. Loss of crown retention was also reported in 2 studies $[66,73]$. The mechanical failure rate for each study was calculated as the number of mechanical failures divided by 


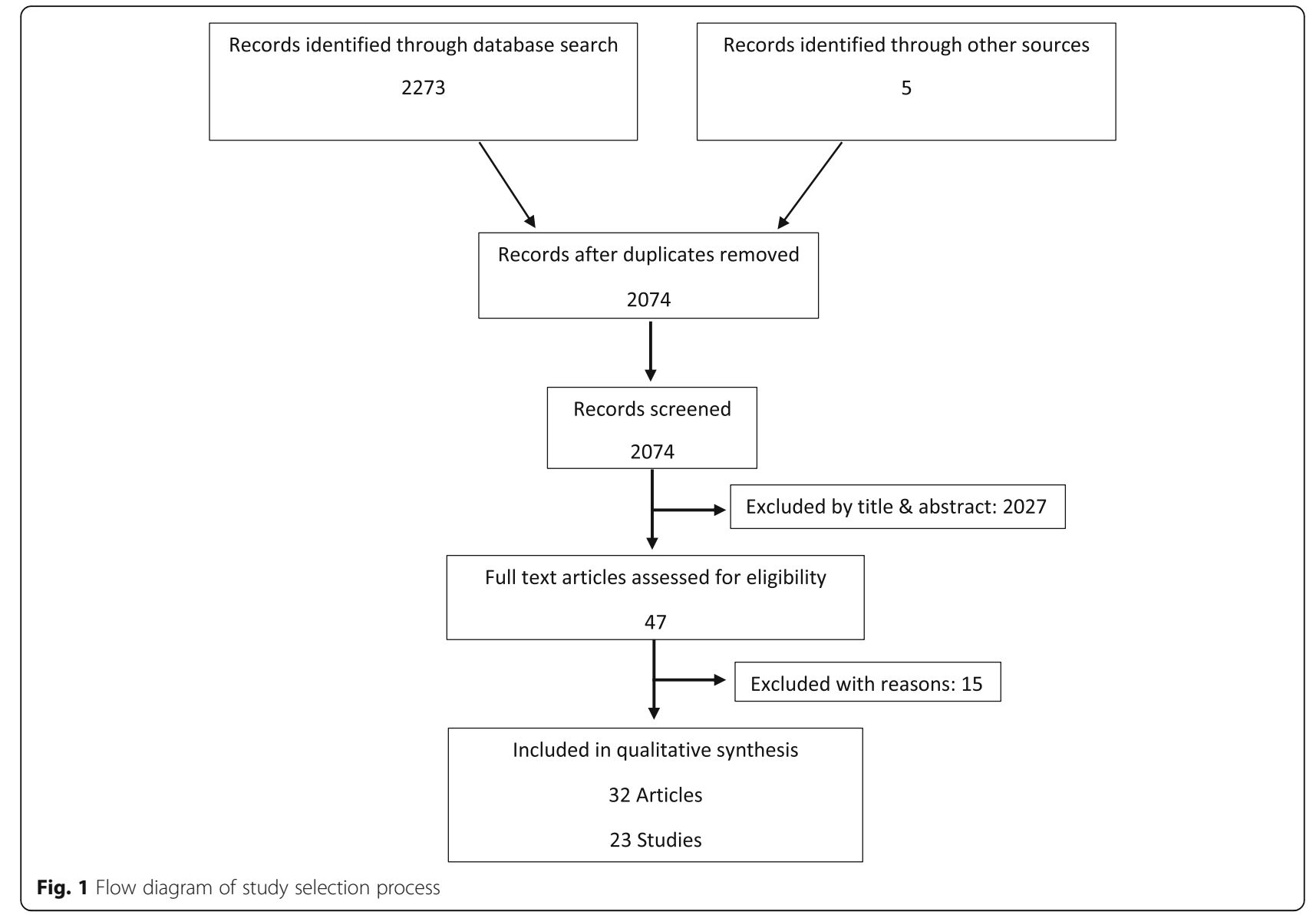

the number of implants and then multiplied by 100 (Table 4).

\section{Esthetic outcomes}

Eleven studies (14 articles) assessed esthetic outcomes (Table 5). The indices used for this purpose were the PES (pink esthetic score), the PES/WES (pink and white esthetic scores), the ICAI index (implant crown esthetic index), and the CIS index (Copenhagen index score).

The PES and PES/WES had good scores of a range of 9-10 and 13-18 respectively. Four studies used PES while three of them contributed to the estimation of overall mean difference in PES between experimental and control group. Wittneben et al. [59] was excluded from the quantitative synthesis since there was not sufficient data for the extraction of mean, standard deviation, and 95\% confidence intervals of PES at each group. Summary measures were combined using random-effects models to minimize effects of between study heterogeneity. Heterogeneity was assessed using the $\mathrm{I}^{2}$ statistic and was distinguished as low $(\leq 25 \%)$, moderate $(25-75 \%)$, or high ( $\geq 75 \%$ ); a p value $<0.10$ was considered statistically significant. Because of the limited number of the studies, publication bias was not evaluated; Egger's test is not applicable in a small number of studies. The difference in mean PES was statistically significant between the two groups in one study [51]. The overall mean difference in PES between the two groups was not statistically

Table 1 Excluded articles with reasons

\begin{tabular}{lc}
\hline Excluded articles & Reason of exclusion \\
\hline Zembic et al. 2009 [32], Sailer et al. 2009 [33], Zembic et al. 2013 [34], Bosch et al. 2018 [35] & Included molar teeth \\
Van Brakel et al. 2012 [36], den Hartog et al. 201 3[37], Rieder et al. 2016 [38] & Irrelevant outcomes \\
Furze et al. 2012 [39], Montero et al. 2012 [40], Schwarz et al. 2012 [41], Hosseini et al. 2013 [42], & Study type (not RCTs) \\
Fenner et al. 2016 [43], Kim et al. 2016 [44], Peng et al. 2017 [45], Asgeirsson et al. 2019 [46] & \\
\hline
\end{tabular}


Table 2 Multiple publications of the same study

- Büchi et al. 2014 [23], Thoma et al. 2016a [47] and Brandenberg et al. 2017 [48] (different outcomes)

- Eisner et al. 2018 [49] is the 3-year follow-up of the abovementioned study (different sample due to loss of follow-up)

- Laass et al. 2019 [50] is the 5-year follow-up of the abovementioned study (different sample due to loss of follow-up)

- Gallucci et al. 2011a and Gallucci et al. 2011b [51, 52] (different outcomes)

- Heierle et al. 2019 [53] is the 3 year follow-up of Thoma et al. 2018a [54] (different sample due to loss of follow-up)

- Thoma et al. 2016b [55] and Thoma et al. 2018b (different outcomes) [56]

- Kraus et al. 2019 [57] is the 3 year follow-up of Thoma et al. 2018b [56] (different sample size due to loss of follow-up)

-Wittneben et al. 2017 [58] and Wittneben et al. 2020 [59] (same sample size)

- Patil et al. 2014 [60] and Patil et al. 2016 [61] and Patil et al. 2017 [62] (different outcomes)

- Gil et al. 2017 [63] and Gil et al. 2019 [64] and Bittner et al. 2020 [65] (different outcomes)

significant (-0.22, -0.84 to 0.41$)$ (Fig. 2). The heterogeneity was low and not statistically significant $\left(\mathrm{I}^{2}=45 \%\right.$; $=0.16$ ).

The PI (papilla index) was used to assess the shape and height of the mesial and distal papillae. Generally, papillae increased through time (Table 5); one study exhibited significant improvement in the papillae in the zirconia abutment group [73]. In some cases [51, 62, 66-68], patient satisfaction was assessed using a visual analog scale (VAS). The VAS scores were generally high in the assessed studies, indicating good patient acceptance.

In 9 studies [13, 22, 23, 54, 55, 65, 70-72] (Table 6), the color of the soft tissues surrounding the abutment was assessed and compared with that of the adjacent or contralateral tooth with the use of a spectrophotometer, and the $\Delta \mathrm{E}$ values were calculated. They were over the clinically acceptable threshold of 3.7 [75] in all cases, and in most studies, zirconia abutments exhibited better values than other materials. One study of experimental pink veneered abutments exhibited better $\Delta \mathrm{E}$ values than those of the conventional zirconia abutments [55]. In another study, an experimental fluorescent zirconia abutment was compared to a conventional white zirconia abutment with promising results, especially close to the gingival margin [72]. Some of these studies also tried to correlate the soft tissue thickness with the color difference.

\section{Biological outcomes}

Biological outcomes were reported in 13 studies (Table 7). Most of the studies reported stability of the plaque and bleeding on probing scores over time, while some studies reported a slight increase in probing depths over time. A study comparing submucosally veneered with non-veneered zirconia abutments exhibited increased probing depths in the veneered group [50]. The mucosal thickness of the peri-implant tissues exhibited increase over time in some cases. The occurrence of a buccal fistula was reported in 2 studies $[15,66]$ and 2 studies reported cases of mucositis (ceramic abutments) $[57,73]$, while mucosal recession was reported in 4 studies $[15,49,52,65]$.

\section{Risk of bias within individual studies}

The risk of bias of the randomized studies was assessed with the RoB 2 tool [31] and is presented in detail in Figs. 3 and 4. Seven studies exhibited an overall low risk of bias, while twelve studies raised some concerns.

\section{Discussion}

Over the years, various implant systems, abutment, and restoration designs and materials have been introduced for the purpose of delivering a functional and naturallooking outcome for a missing tooth. Abutment's material, method of fabrication, transmucosal macro-design, and connection, are considerations critical to the rehabilitation of a single anterior edentulous space with an implant. This systematic review, following a predetermined protocol, aimed to assess the esthetic, biological, and mechanical outcomes as well as the survival of the different types of abutments used for single-implant restorations in the anterior region. The synthesis of the individual data of the included RCTs led to the following outcomes.

\section{Mechanical outcomes}

During the last decade, the internal connected zirconia abutments seem to be the most used abutments for anterior single implant restorations. In this review, only one study [15] reported the use of externally connected alumina abutments. Generally, the internal abutment connection is considered to reduce the incidence of screw loosening [76], which was also demonstrated in this systematic review; only 2 studies of internally connected abutments mentioned screw loosening. However, the internally connected zirconia abutment was associated with a higher incidence of fracture due to the weakest area being the neck of the abutment where the forces are concentrated. More specifically, Thoma et al. 2016 [47] reported a 5\% fracture rate of the customized zirconia abutments in 1 year, which is a high percentage for such a short period of time. Similar results were noted by Heierle et al. 2019 [53] after a 3-year follow-up where one fracture of a screw-retained one-piece zirconia abutment took place. A more increased fracture rate (13.6\%) was noted in a study comparing screw retained and cement retained single-implant restorations [57]. Most 


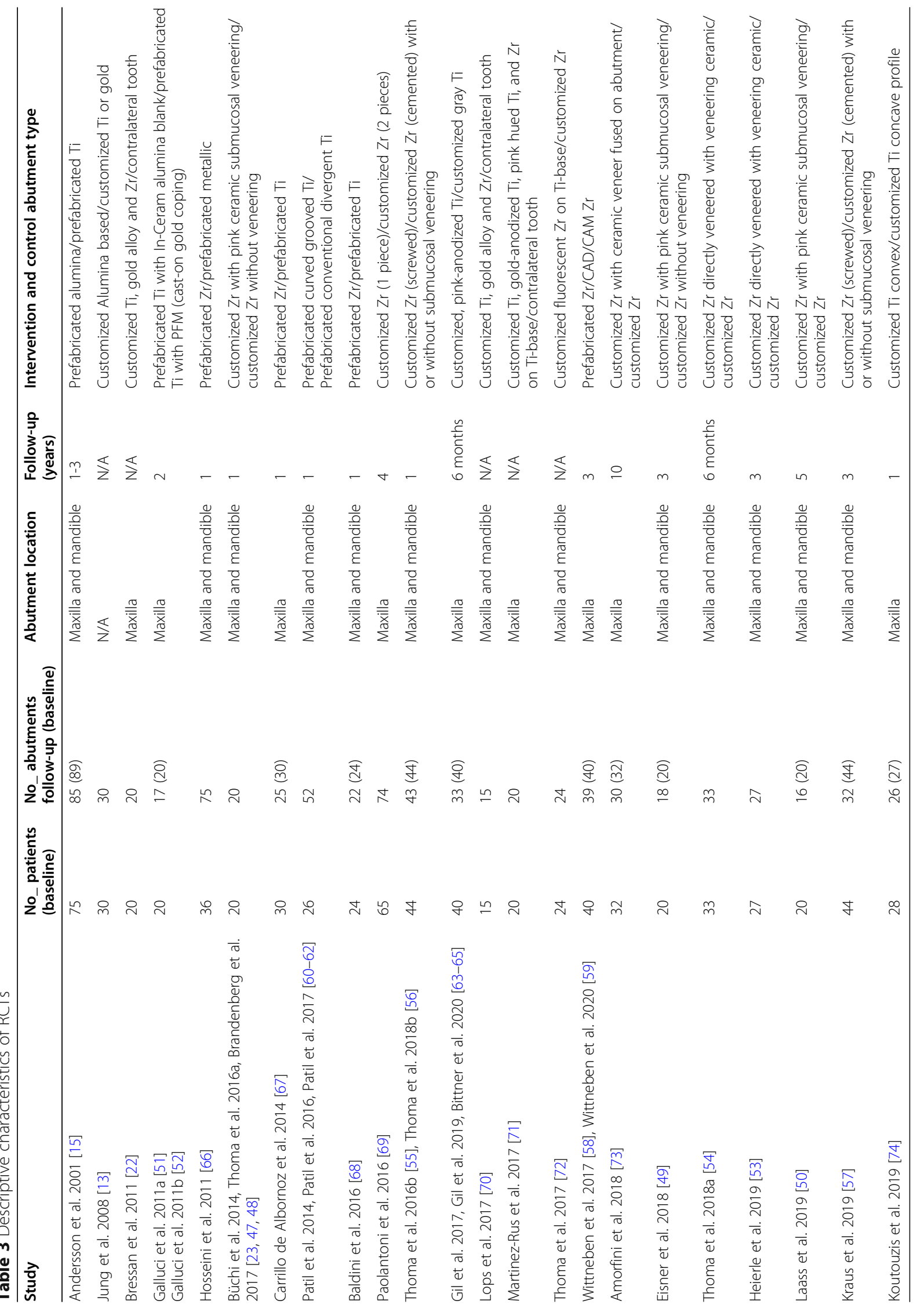




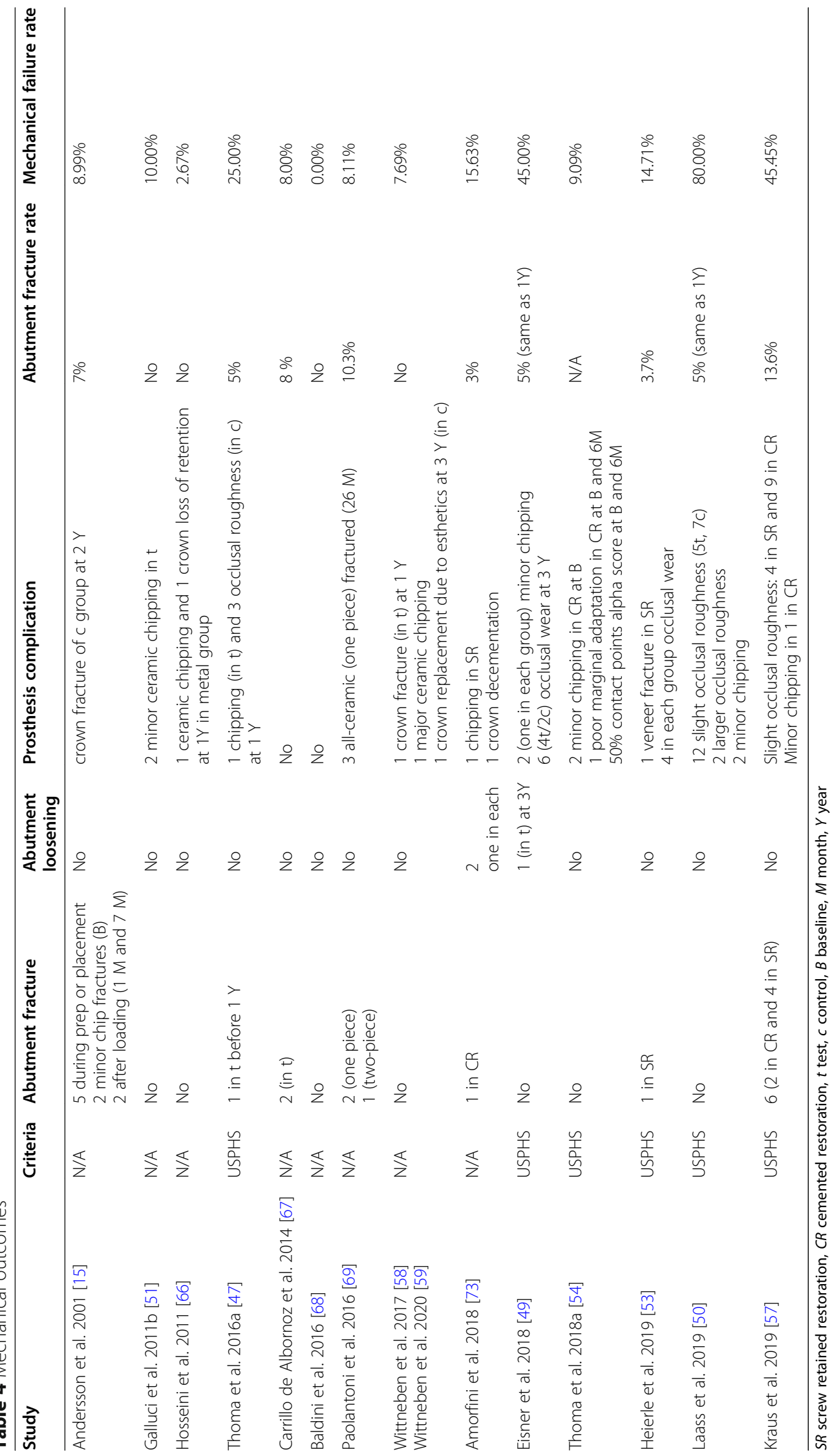


Table 5 Esthetic outcomes

\begin{tabular}{|c|c|c|}
\hline Study & Indices & Esthetic outcomes \\
\hline $\begin{array}{l}\text { Galluci et al. 2011a [51] } \\
\text { Galluci et al. 2011b [52] }\end{array}$ & PES, WES & $\begin{array}{l}\mathrm{PH}, \mathrm{CLt}, \mathrm{Cli}, \mathrm{KMi}, \mathrm{KMt} \text { similar between groups }(\mathrm{p}>0.05) \\
\text { Significant increase in the mean PH (mesial and distal) between } \mathrm{B} \text { and } \mathrm{Cl} \text { and } \\
\text { between } \mathrm{Cl} \text { and } 1 \mathrm{Y} \\
\text { Mean } \mathrm{CLi} \text { between } \mathrm{Cl} \text { and } 1 \mathrm{Y} p>0.05 \text {, between } 1 \mathrm{Y} \text { and } 2 \mathrm{Y} \text { significant recession } \\
\text { Mean KM } \mathrm{p}>0.05 \text { between groups } \\
\mathrm{PES} \text {, WES between groups } \mathrm{P}>0.05 \text {. PES was higher than WES (total score } \\
\text { approximately 13) }\end{array}$ \\
\hline Hosseini et al. 2011 [66] & $\mathrm{CIS}$ & $\begin{array}{l}\text { Crown morphology between groups }(p>0.05) \\
\text { Color match better for ceramic group }(p=0.03) \\
\text { Mucosal dicoloration and } \mathrm{PI} p>0.05 \text { between groups (papilla index improvement } \\
\text { from } B \text { to } 1 Y \text { in both groups) } \\
\text { Overall CIS between groups } p>0.05\end{array}$ \\
\hline Brandenberg et al. 2017 [48] & Modified PI & $\begin{array}{l}\text { PI increased between } B \text { and } 6 \mathrm{M} \text { and then slightly decreased }(p>0.05) \\
\text { Implants lower PI than natural teeth }(p<0.05) \\
1 \mathrm{~mm} \text { recession in one implant (control) }\end{array}$ \\
\hline Carrillo de Albornoz et al. 2014 [67] & $\begin{array}{l}\text { ICAI } \\
\mathrm{Pl}\end{array}$ & $\begin{array}{l}\text { ICAl-crown scores: satisfactory in t group, moderate in c group }(p>0.05) \\
\text { ICAl-mucosa scores: improved color and surface of soft tissues with zirconia }(p= \\
0.065) \\
\text { Zirconia: higher PI }(p=0.053)\end{array}$ \\
\hline Patil et al. 2017 [62] & $\mathrm{PES} / \mathrm{PI}$ & $\begin{array}{l}p>0.05 \text { between PES for } t \text { and } c \text { at } B \text { and } 1 Y \\
\text { PES slightly improved after } 1 Y \text { in both groups }(p<0.05 \text { ) } \\
p>0.05 \text { between PI of } t \text { and } c \text { (positive association between papillary fill and bone }\end{array}$ \\
\hline
\end{tabular}

Baldini et al. 2016 [68] ICAI and PI

Bittner et al. 2020 [65]

Wittneben et al. 2020 [59]

Amorfini et al. 2018 [73]

Eisner et al. 2018 [49]

Thoma et al. 2018a [54]

Laass et al. 2019 [50]

Kraus et al. 2019 [57]

Modified PI
N/A

MPES and WES height between implant and tooth)

ICAI-mucosa scores: higher at $1 \mathrm{M}(\mathrm{p}=0.01)$ for zirconia group (improved color and surface of soft tissues).

Both groups: increase of PI between B and 12 M $(p<0.05)$

Mean recession at $6 \mathrm{M}(\mathrm{p}=0.60)$ : Pink, thin: $1.37 \mathrm{~mm} /$ pink, thick: $1.28 \mathrm{~mm}$

Gray, thin: $1.99 \mathrm{~mm} /$ gray, thick: $1.13 \mathrm{~mm}$

The recession and collapse showed no correlation to color

1 Y: Mean PES: group A: 7/group B: No difference over time

7.65

Mean WES: group A: 8.28/group B:

8.50

3 Y: Mean PES: group A: 7.76/group PES higher between $B$ and 3 Y for group A B: 7.32 $(p=0.04)$

Mean WES: group A: 8.88/group B:

8.56

Significant differences in implant crown length between $B$ and $3 Y(p=0.004)$ and $6 \mathrm{M}$ and $3 \mathrm{Y}(\mathrm{p}=0.012)$

Implant crown/tooth Implant crown and tooth crown values similar between groups $/ \mathrm{p}=0.01$ for crown index intragroup changes in $10 \mathrm{Y}$

$\mathrm{Pl} \quad \mathrm{Pl}$ increased in both groups at $2 \mathrm{Y}(\mathrm{p}<0.05)$ and then stabilized

PES/WES PES $7.5(S R), 7(C R)(p>0.05)$

WES $7.9(\mathrm{SR}), 7.4(\mathrm{CR})(\mathrm{p}>0.05)$

$p>0.05$ for PI between groups at $3 \mathrm{Y}$ and for intragroup changes (c slight increase in $\mathrm{Pl} / \mathrm{t}$ slight decrease in PI mesially)

No recession in $\mathrm{t}$ at $3 \mathrm{Y} /$ in $\mathrm{c}$ recession at $3 Y-0.11 \mathrm{~mm}(\mathrm{p}=0.02)$

Modified PI Slight improvement in PI in both groups over time $(p>0.05)$ and no difference between groups

Crown height stable over time

MT slightly superior in SR group $(p>0.05)$

Modified PI $\mathrm{mPI}$ increased over time in the $\mathrm{c}$ and decreased in the $\mathrm{t}$

Modified PI $\quad \mathrm{mPl}: \mathrm{p}>0.31$ between two groups

Median mucosal level changes were $0.0 \mathrm{~mm}$ at both SR and CR between $\mathrm{B}$ and $3 \mathrm{Y}$ $(p>0.44)$

$K M t$ width of the buccal keratinized mucosa (gingiva) at the adjacent teeth, $C L t$ distance between the mid-facial gingival margin and the incisal edge of adjacent teeth, $K M i$ width of the buccal keratinized mucosa at the implant site, Cli distance between the mid-facial gingival margin and the incisal edge of implant crown, $\mathrm{PH}$ papilla height, $B$ baseline, $Y$ year, $M$ months, $C R$ cemented restoration, $S R$ screw retained restoration, $C l$ crown insertion, $t$ test, $C$ control 


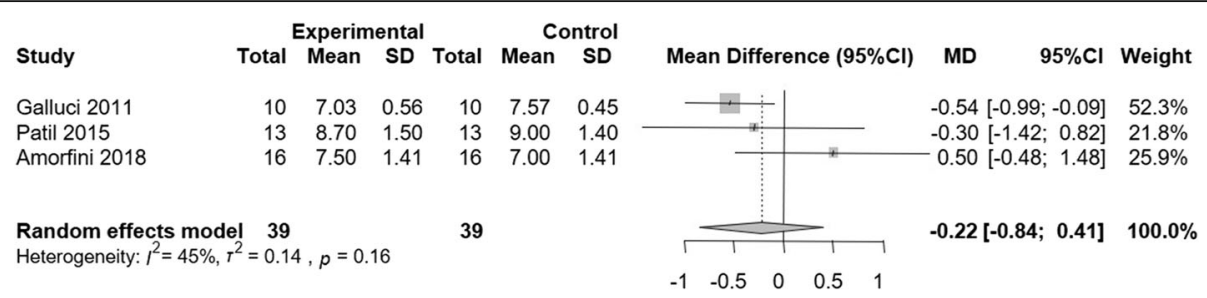

Fig. 2 Forest plot of the overall mean difference in PES between experimental and control groups

fractures were observed in the screw retained group, raising the question of whether the type of crown retention might influence the fracture resistance of the reconstruction. The authors proposed that the cementation gap in cemented restorations might compensate the stresses and reduce the fracture risk [57]. However, most fractured abutments occurred in premolar teeth, so the implant site might be another factor that can contribute to the increased fracture rate. It is noteworthy that in 2 studies, the ceramic abutment fracture took place during the screw tightening $[15,67]$. This might be a result of stress during laboratory preparation in order to individualize the prefabricated abutments, often resulting in very thin abutment walls that might not withstand the torquing forces.

Two studies examining the same type of abutments, Baldini et al. [68] resulted in no technical problems after 1 year while Carrillo de Albornoz et al. [67] reported zirconia abutment fractures after the same time period. Both zirconia and titanium abutments were restored with metal-ceramic crowns in the first study [68], while all-ceramic crowns covered the zirconia abutments in the other study [67]. The type of restoration may have been a factor on the stress distribution on the abutment. However, this is only a speculation and the short followup period (1 year) further reduces the strength of the findings. It must be noted that no fractures were reported in the studies with internally connected titanium abutments, indicating the higher strength of these abutments $[77,78]$.

Implant diameter has been postulated to influence the fracture resistance of an abutment, with narrow implants being more susceptible [77]. In this systematic review, out of 7 narrow abutments, 2 fractures were reported [67], while one study of regular diameter implants reported a $3 \%$ fracture rate [73]. In the other relevant studies, the implant diameter was not specified, therefore making the investigation of this hypothesis difficult due to lack of adequate evidence.

Two studies reported a new type of hybrid abutment, a zirconia abutment cemented on a titanium base [71, 72]. This type of abutment is considered to improve the performance of zirconia abutments by mechanically reinforcing the abutment and providing a more stable internal connection. No mechanical outcomes were reported in the included studies. Regarding the zirconia abutments that were subgingivally modified with pink ceramic to improve esthetics, only one abutment fractured [49], although an in vitro study [79] concluded that veneering the zirconia could influence the flexural strength of the abutment.

Due to the heterogeneity of the studies included, the different follow-up periods, and the fact that some studies did not report the time of abutment failure, it was difficult to calculate the abutment survival rate. However, the percentage of the abutment fracture requiring replacement was considered the most significant complication and was estimated at $4.26 \%$.

\section{Esthetic outcomes}

The effect of the abutment and restoration on the final shade of the peri-implant mucosa has been explored in some included studies. The most objective measurement of this effect is the spectrophotometric measurement and the calculation of the color difference $(\Delta E)$ of the implant mucosa or the implant crown to that of the natural tooth. Four studies [13, 22, 70, 71] compared the esthetics of titanium, gold, and ceramic (zirconia or alumina) abutments. All abutments exhibited clinically visible tissue discoloration with titanium abutments exhibiting significantly higher $\Delta \mathrm{E}$ than gold or zirconia.

The tissue thickness has been considered to influence the effect of the abutment on the final shade of the periimplant mucosa [12], although it was not fully supported by the included studies. Martinez et al. [71] compared titanium, gold-hued titanium, pink-hued titanium, and zirconia with Ti-base abutments and interestingly, the gold titanium esthetics were almost comparable with zirconia, especially in thicker biotypes, making it a better choice than unhued titanium and even pink titanium. In this study, it was noted that the zirconia abutments were cemented on a Ti-base that might result in some shine through and influence the results, reducing the color difference between gold and zirconia. Another study compared pink and gray titanium abutments placed on implants with either pink or gray-hued collar [65]. The 
Table 6 Mean color difference $(\Delta \mathrm{E})$ data

\begin{tabular}{|c|c|c|c|c|}
\hline \multirow[t]{2}{*}{ Study } & \multirow[t]{2}{*}{ Mean $\Delta \mathrm{E}$ values } & \multirow{2}{*}{$\begin{array}{l}\text { Mean mucosal } \\
\text { thickness }(\mathrm{mm})\end{array}$} & \multicolumn{2}{|c|}{ Mean $\Delta \mathrm{E}$ values according to soft tissue thickness } \\
\hline & & & Thin $(\leq 2 \mathrm{~mm})$ & Thick (> $2 \mathrm{~mm})$ \\
\hline Thoma et al. 2018a [54] & $\begin{array}{l}\text { CM: } 5.51 \pm 1.56 / S R: \\
7.42 \pm 5.05(p>0.05)\end{array}$ & $\begin{array}{l}\text { CM: } 3.38 \pm 0.99 / S R: \\
4.06 \pm 1.06\end{array}$ & N/A & N/A \\
\hline Buchi et al. 2014 [23] & $\begin{array}{l}\text { t: } 6.3 \pm 2.2 / c: 4.6 \pm \\
1.8(p>0.05)\end{array}$ & $\begin{array}{l}\text { t: } 1.6 \pm 0.4 / c: 1.8 \pm \\
0.7(p>0.05)\end{array}$ & $\mathrm{t}: 6.2 \pm 1.9 / \mathrm{c}: 4.2 \pm 1.6(\mathrm{p}>0.05)$ & $\mathrm{t}: 6.5 \pm 4.6 / \mathrm{c}: 4.9 \pm 2.1(p>0.05)$ \\
\hline Thoma et. al 2016b [55] & $\begin{array}{l}\text { Abutment vs control } \\
\text { tooth: P: } 7.55 \pm 3.02 \\
\text { W: } 7.52 \pm 2.29 \\
\text { Crown vs control } \\
\text { tooth: P: } 6.16 \pm 2.48 \\
\text { W: } 8.31 \pm 3.33\end{array}$ & N/A & $\begin{array}{l}\text { Crown vs control tooth: } \\
P: 4.50 \pm 1.93 \\
W: 9.72 \pm 3.82 \\
(p>0.05)\end{array}$ & $\begin{array}{l}\text { Crown vs control tooth: } \\
\text { P: } 6.88 \pm 2.45 \\
W: 8.31 \pm 2.98 \\
(p>0.05)\end{array}$ \\
\hline Jung et al. 2008 [13] & $\begin{array}{l}\Delta \text { E implant: } 7.4-7.6 \text { ( } p \\
>0.05 \text { between } \\
\text { groups) } \\
\Delta \text { E tooth-implant } \\
\text { overall: All-ceramic } \\
3.4 \pm 1.4 \\
\text { PFM } 5.2 \pm 2.3(p> \\
0.05) \\
\Delta E \text { tooth-implant } \\
\text { grafted ( } p>0.05) \\
\Delta \text { E tooth-implant } \\
\text { non-grafted ( } p= \\
0.04)(P F M \text { higher) }\end{array}$ & $\begin{array}{l}\text { All-ceramic: } 3.4 \pm 0.8 \\
\text { PFM: } 2.9 \pm 0.9(p>0.05)\end{array}$ & N/A & N/A \\
\hline Bittner et al. 2020 [65] & $\begin{array}{l}\Delta \text { E when change } \\
\text { from gray to pink } \\
\text { abutment still above } \\
\text { clinical threshold }\end{array}$ & N/A & 6M: t:6.2/c:6.14 & 6M: t: 8.42 /c:7.96 \\
\hline $\begin{array}{l}\text { Martinez-Rus et al. } 2017 \\
\text { [71] }\end{array}$ & $\begin{array}{l}\text { Soft tissue level: Ti: } \\
11.56 \pm 3.4 \\
\text { GTi: } 8.96 \pm 3.1 \\
\text { PTi: } 10.68 \pm 4.2 \\
\text { Zr Ti-base } 6.06 \pm 3.2 \\
\text { Coronal level: Ti: } \\
\text { 10.42 } \pm 6.3 \\
\text { GTi: } 9.16 \pm 6.5 \\
\text { PTi } 8.66 \pm 6.1 \\
\text { Zr Ti-base } 5.76 \pm 2.9\end{array}$ & $1.63 \pm 0.64 \mathrm{~mm}$ & $\begin{array}{l}\text { N/A } \\
\text { Correlation between } \Delta E \text { and thickness } \\
\text { Ti: } p=0.024 \\
\text { PTi: } p=0.048\end{array}$ & N/A \\
\hline Lops et al. 2017 [70] & $\begin{array}{l}\text { Gold: } 11.43 \pm 4.05 \\
\text { Ti: } 13.55 \pm 6.91 \\
\text { Zr: } 11.37 \pm 4.67(p> \\
0.05) \\
\text { *all over clinical } \\
\text { threshold } \Delta \text { E } 8.47\end{array}$ & $2.57 \pm 0.5 \mathrm{~mm}$ & $\begin{array}{l}\text { G: } 9.82 \\
\text { Ti: } 13.86 \\
\text { Zr: } 10.86(p>0.05)\end{array}$ & N/A \\
\hline Bressan et al. 2011 [22] & $\begin{array}{l}\text { G: } 8.9 \pm 0.4(\mathrm{SE}) \\
\text { Ti: } 11 \pm 0.4(\mathrm{SE})(\mathrm{p}< \\
0.05) \\
\text { Zr: } 8.5 \pm 0.4(\mathrm{SE}) \\
{ }^{*} \text { over } \Delta \mathrm{E} 3.7\end{array}$ & N/A & $\begin{array}{l}\text { G: } 8.6 \pm 1.4 \text { (SE) } \\
\text { Ti: } 9.5 \pm 1.4 \text { (SE) } \\
\text { Zr: } 7.5 \pm 1.4 \text { (SE) }\end{array}$ & $\begin{array}{l}\text { G: } 9.1 \pm 0.8(\mathrm{SE}) \\
\text { Ti: } 11.9 \pm 1.2(\mathrm{SE}) \\
\text { Zr: } 8.9 \pm 0.7(\mathrm{SE})(p>0.05)\end{array}$ \\
\hline Thoma et al. 2017 [72] & $\begin{array}{l}\Delta \mathrm{E} \text { abutment test: } \\
8.27 \pm 4.03 \\
\Delta \mathrm{E} \text { abutment control: } \\
8.49 \pm 3.59 \\
\Delta \mathrm{E} \text { crown test: } 8.32 \pm \\
3.57 \\
\Delta \mathrm{E} \text { crown control: } \\
7.61 \pm 4.03 \quad(\mathrm{p}> \\
0.05)\end{array}$ & N/A & $\begin{array}{l}\Delta \text { E crown c vs } \Delta \text { E crown t: } \\
-2.08 \pm 3.82 \\
(p<0.05)\end{array}$ & $\begin{array}{l}\Delta \mathrm{E} \text { crown c vs } \Delta \mathrm{E} \text { crown } \mathrm{t}: \\
0.75 \pm 2.30\end{array}$ \\
\hline
\end{tabular}

${ }^{*} \Delta E$ color difference, $C R$ cemented restoration, $S R$ screw retained restoration, $M$ months, $t$ test, $c$ control, $Z r$ zirconia, $T i$ titanium, $G$ gold, $P$ pink, $W$ white 
Table 7 Biological outcomes

\begin{tabular}{|c|c|c|}
\hline Study & $\begin{array}{l}\text { Implant survival } \\
\text { rates }\end{array}$ & Biological-clinical outcomes \\
\hline Andersson et al. 2001 [15] & $100 \%$ & $\begin{array}{l}p>0.05 \text { for plaque and bleeding measurements between abutments at } 1 Y \\
\text { Buccal fistula: } 1 \text { in } c \text {, recession: } 1 \text { in } t / 2 \text { in } c\end{array}$ \\
\hline Galluci et al. 2011b [51] & $100 \%$ & $\begin{array}{l}p<0.05 \text { for FMPS at } 2 Y \text { between } t \text { and } c \text { (increased scores in the all-ceramic group) } \\
\text { FBIC } p<0.05 \text { between } B \text { and } \mathrm{Cl} \text { at } 1 Y \text { and } 2 Y\end{array}$ \\
\hline Hosseini et al. 2011 [66] & $100 \%$ & $\begin{array}{l}p>0.05 \text { for } \mathrm{mPI} \text { and } \mathrm{mBl} \text { between groups at } \mathrm{B} \text { and } 1 \mathrm{Y} \\
\text { Ceramic group } 1 \mathrm{Y}: 1 \text { fistula, } 3 \text { suppuration on probing, } 2 \text { PPD } \geq 5 \mathrm{~mm} \text {, } 1 \text { weak pain } \\
\text { (most not ideal marginal adaptation }-\mathrm{p}<0.05 \text { for ceramic group) } \\
\text { Metal group } 1 \mathrm{Y}: 3 \text { suppuration and PPD } \geq 5 \mathrm{~mm}\end{array}$ \\
\hline Brandenberg et al. 2017 [48] & $100 \%$ & $\begin{array}{l}\text { PPD no difference between groups/ mean PPD of all implants higher at B than } 1 Y(P< \\
0.05) \\
\text { BOP significantly increased in both groups after } 1 \text { Y (non-significant between group } \\
\text { comparison) } \\
\text { KM, MT slight increase over time }(p>0.05) \\
\text { At } 1 \text { Y } 1 \text { implant (control) small recession }\end{array}$ \\
\hline Carrillo de Albornoz et al. 2014 [67] & $100 \%$ & $\begin{array}{l}\text { PPD, REC: } p>0.05 \text { between } B \text { and } 12 \mathrm{M} \text { or between groups } \\
\text { FMBS: improvement for both groups from } B \text { to } 1 \mathrm{M}(\mathrm{p}<0.05)\end{array}$ \\
\hline Patil et al. 2017 [62] & $100 \%$ & $p>0.05$ for PPD between groups at $B$ and at $1 \mathrm{Y}$ \\
\hline Baldini et al. 2016 [68] & $100 \%$ & $\begin{array}{l}\text { PPD, BOP, REC: } P>0.05 \text { between } B \text { and } 12 \mathrm{M} \text { or between groups } \\
\text { MT: no changes }\end{array}$ \\
\hline Paolantoni et al. 2016 [69] & $100 \%$ & $\mathrm{PI}, \mathrm{BI} p>0.05$ between groups \\
\hline Thoma et al. 2018b [56] & $100 \%$ & $\begin{array}{l}\text { PD } p>0.05 \text { at } B, 6 \mathrm{M} \text {, and } 1 \mathrm{Y} \text { between groups and intragroup changes } \\
\text { Plaque changes non-significant } \\
\text { BOP increase between } B \text { and } 1 Y \text { in } C R \text { white group significant } \\
\text { BOP not significant difference between groups }\end{array}$ \\
\hline Wittneben et al. 2020 [59] & $100 \%$ & $\begin{array}{l}\text { 1Y: Low mPLI, mSBI, PD ( } p>0.05 \text { between groups) } \\
\text { Mean KM } 3.6 \mathrm{~mm} \\
\text { Group B KM significant difference between B and } 1 Y \\
3 Y: p>0.05 \text { between groups for } \mathrm{mPLI} \text {, mSBI, PPD, and KM } \\
\text { Within each group } p<0.05 \text { for mPLI between time points ( } B \text { and } 6 \mathrm{M}, 6 \mathrm{M} \text { and } 1 \mathrm{Y}, 6 \\
\mathrm{M} \text { and } 3 \mathrm{Y} \text { ) }\end{array}$ \\
\hline Amorfini et al. 2018 [73] & $100 \%$ & $\begin{array}{l}2 \text { mucositis cases ( } 1 \text { in each group) } \\
\text { BOP, PPD, mPl: } p>0.05\end{array}$ \\
\hline Eisner et al. 2018 [49] & $100 \%$ & $\begin{array}{l}\mathrm{PD}, \mathrm{BOP}, \mathrm{Pl} \text { at } 3 \text { Y } p>0.05 \text { between groups } \\
\text { MT higher at } 3 Y \text { in implants than teeth }(p<0.05) \\
\text { MT higher in control }(p=0.013) \text { at } 3 Y \\
\text { MT implant increased over time in both groups }(p<0.05) \\
\text { KM test } 3 Y 3.22 \mathrm{~mm} \text { vs KM control } 3 Y 3.67 \mathrm{~mm}(p=0.037)\end{array}$ \\
\hline Thoma et al. 2018a [54] & $100 \%$ & $\begin{array}{l}\text { PCR, PPD, } K T \text { stable over time and comparable between implants and teeth } \\
\text { Median BOP at B: } 33 \% \text { CR, } 17 \% \text { SR } \\
\text { Median BOP at } 6 \mathrm{M}: 17 \% \text { CR, } 17 \% \text { SR }\end{array}$ \\
\hline Heierle et al. 2019 [53] & $100 \%$ & N/A \\
\hline Laass et al. 2019 [50] & $100 \%$ & $\begin{array}{l}p=0.042 \text { in PD at } 5 Y \text { between groups (increased scores in the test group)/intragroup } \\
\text { differences between } B \text { and } 5 Y \text { not significant } \\
\text { In the } c \text { group KM was a little wider and the MT was higher }(p>0.05) \\
p>0.05 \text { for PCR, BOP }\end{array}$ \\
\hline Kraus et al. 2019 [57] & $81.8 \%$ & $\begin{array}{l}\text { Median PD } 3.0 \mathrm{~mm} \text { in SR and } 3.0 \mathrm{~mm} \text { in } C R(p=0.664) \\
\text { Intragroup changes in PD from } B \text { to } 3 Y \text { were statistically significant }(p<0.05) \\
\text { BOP and PCR: } p>0.05 \text { between groups } \\
\text { Median KM between implants (SR) and control teeth significant ( } p=0.007) \\
\text { Median KM between implants (CR) and control teeth non-significant }(p=0.42) \\
\text { MT } p>0.05 \text { between implants and teeth in both groups and in intragroup comparison } \\
\text { (B vs } 3 \text { Y) } \\
\text { One implant from CR was lost at } 9 \text { M and one at } 3 Y \\
\text { At } 3 \text { Y } 2 \text { implants peri-implant mucositis (one in } C R \text { and one in SR) }\end{array}$ \\
\hline Koutouzis et al. 2019 [74] & $96.3 \%$ & $\begin{array}{l}\text { Plaque, BOP, and PPD at crown placement and } 1 \text { Y ( } 1 \text { Y PPD: CX: } 74.4 \% \text { PD }<3,25.6 \% \\
\text { PD 4-5 mm, CV: } 66.7 \% \text { PD }<3,32.1 \% \text { PD } 4-5 \mathrm{~mm}, 1.2 \% \text { PD } \geq 6 \mathrm{~mm} \text { ): no statistical differ- } \\
\text { ence between groups } \\
\text { Marginal mucosa position changes } p>0.05 \text { between groups (correlation between } \\
\text { mucosa position and buccal bone thickness) }\end{array}$ \\
\hline
\end{tabular}

PPD pocket probing depth, $B O P$ bleeding on probing, $K M$ width of keratinized mucosa, $P C R$ plaque control record, $K T$ keratinized tissue, $G /$ simplified gingival index, $\mathrm{mPLI}$ or MPI modified plaque index, $S B I$ sulcus bleeding index, $R E C$ recession index, FMBS full mouth bleeding score, DIB distance from implant shoulder to the first bone to implant contact, FMPS full mouth plaque score, $F B I C$ first bone to implant contact, $M T$ mucosal thickness, $B$ baseline, $Y$ year, $C R$ cemented restoration, $S R$ screw-retained restoration, $c$ control, $t$ test 

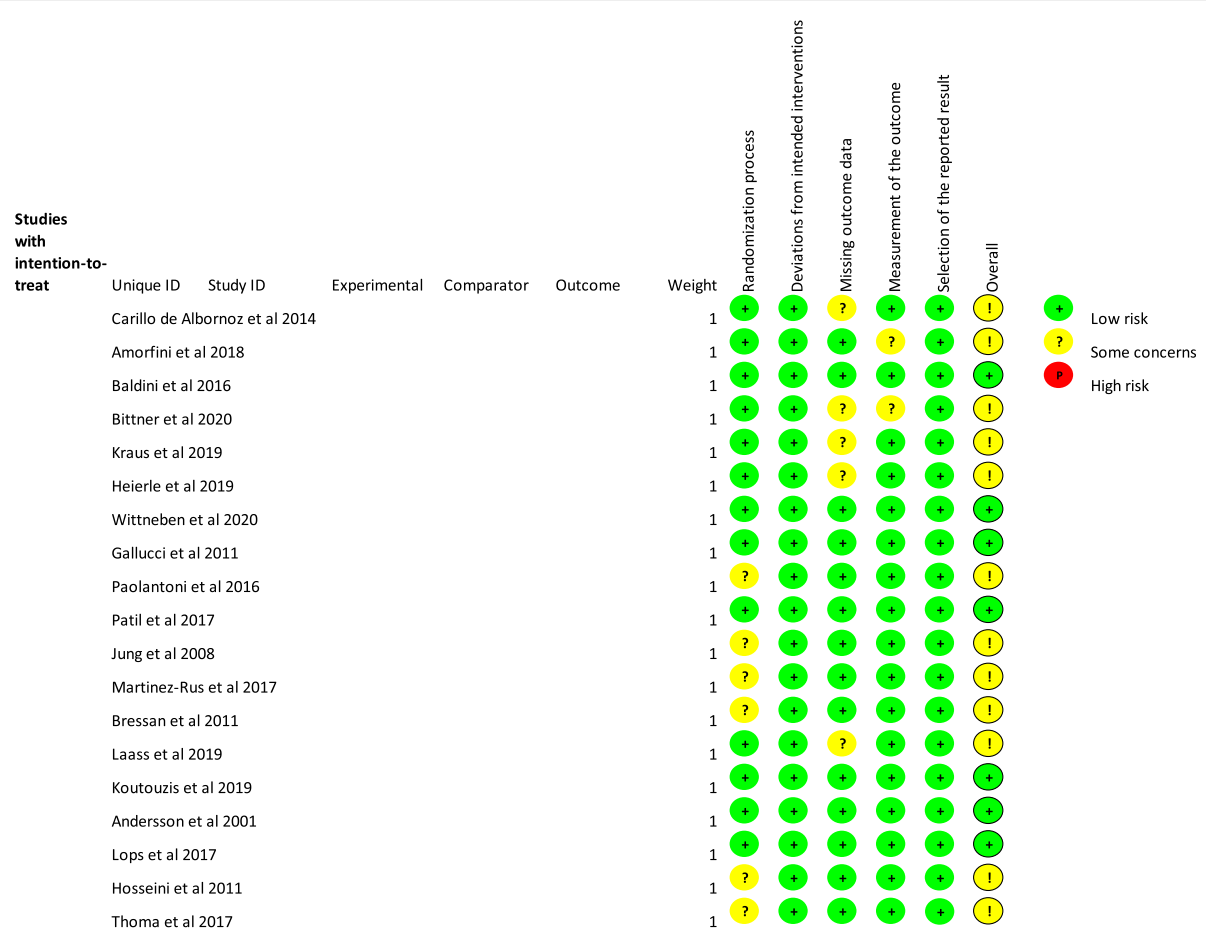

Fig. 3 Risk of bias of the included studies

pink abutments reduced the $\mathrm{a}^{*}$ value $\Delta \mathrm{E}$, resulting in redder gingiva that appeared more natural, regardless of the implant color, especially in thin biotype cases.

It is therefore evident that zirconia abutments are more esthetic. However, due to the bright white color of these abutments, they cause discoloration in the soft tissues, especially if compared to the mucosa of the natural teeth. For better esthetic integration, techniques modifying this color of zirconia by either veneering it with colored ceramic or by using fluorescent zirconia were proposed. The pink veneered zirconia abutments were compared with the conventional white ones and a nonstatistically significant, more intense discoloration was noted with the veneering, possibly as a result of the translucency of the pink ceramic, which reduced the $\mathrm{L}^{*}$ value and resulted in a grayish discoloration [23]. A subsequent study at the same university used a slightly more opacious pink ceramic with marked improvement [55]. The veneering technique improved esthetics regardless of the tissue thickness, although the $\Delta \mathrm{E}$ was still above the clinically acceptable. It was confirmed that the tissue thickness influences the color integration of the

\section{As percentage (intention-to-treat)}

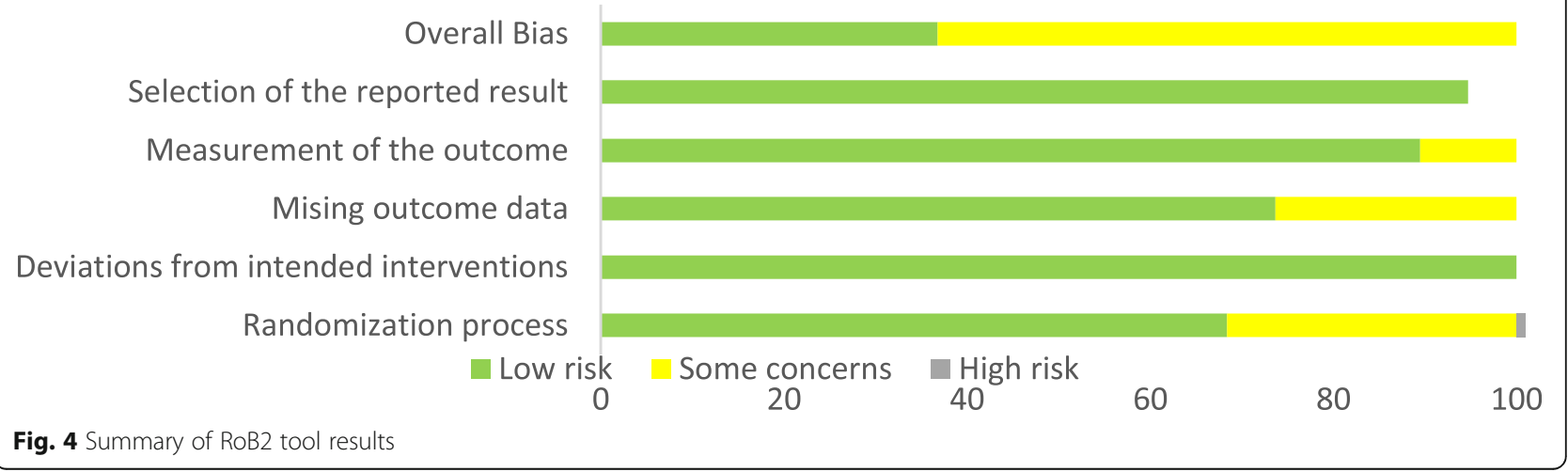


abutment, and the non-veneered abutments exhibited better color match with the natural teeth in cases of thickness $>2 \mathrm{~mm}$. It was also noted that the lowest color difference was recorded in thin biotypes with pink veneering, supporting the hypothesis that the modification is especially important in cases with thin tissues. Finally, no significant difference was found between fluorescent zirconia abutments compared with conventional one-piece zirconia abutments [72]. However, in thin biotypes, white zirconia showed better results, maybe due to the fact that the fluorescent abutments were cemented on a titanium base, which may have been visible through the thin tissues, decreasing the lightness. The use of two different abutment designs (two-piece with Ti-base and one-piece) was a limitation of this study, not allowing to fully investigate the impact of the fluorescence.

Another study [58] investigated the influence of the crown retention (screw-retained vs cement retained) on the esthetic performance of zirconia abutments; however, no significant difference was noted between the two groups and all abutments resulted in a clinically visible discoloration of the mucosa, even though the mean mucosal thickness was over $3 \mathrm{~mm}$.

The esthetic outcomes of the different implant abutments were also assessed using relevant indices (PES, WES, ICAI, CIS) as well as recording patient satisfaction. Most studies comparing the esthetic outcome between ceramic and titanium abutments revealed no significant differences [51, 67, 68]. On the contrary, Hosseini et al. [66] observed a better crown color match for all-ceramic restorations, although the mucosal discoloration was evident with both materials.

An increase in the papilla index score was observed over time $[51,67,68]$. The papillary response was probably influenced more by the abutment shape than the material as no significant differences in PI scores were noted between the ceramic and titanium abutments. The comparison between the types of retention (screw versus cement retained) of ceramic abutments [54, 57, 73] or between CAD/CAM and prefabricated abutments [58] exhibited similar good esthetic results. Nevertheless, in the clinical experience of the author's customized abutments provide better support to the soft tissues, which is especially needed in high scalloped tissue cases. Additionally, two studies of modified zirconia abutments $[50,57]$, revealed no significant difference between the tested abutments and the conventional ones. Another study [74] comparing the effect of macro-morphology (convex versus concave) of titanium abutments on esthetics resulted in similar results on both groups and an increase in papilla was noted over time.

With respect to patient satisfaction, in most cases, the scores were quite high and no difference between materials was noted. In studies where the patient satisfaction was compared with the clinician's assessment, a discrepancy was noted; the patients were more satisfied than the dental practitioners, confirming the notion that individuals perceive esthetic deviations to a lesser extent $[66,67]$. However, when patients were dissatisfied, crown color and tissue morphology were the main reasons they reported [66].

\section{Biological outcomes}

The findings of this systematic review led to similar scores of probing depths, bleeding on probing and mucosal stability between ceramic and titanium abutments $[15,67,68]$ which is comparable with the findings of a previous systematic review [27]. However, Hosseini et al. [66] concluded that the most biological complications were related to all-ceramic restorations, most likely because of the lack of ideal marginal adaptation, due to the use of pre-sintered zirconia copings.

The impact of the abutment macro-morphology on the soft tissue stability and health was also assessed. No significant difference in mucosal alterations was present between curved or concave and convex titanium abutments $[60,74]$. Therefore, the new concept of manufacturing an abutment with a concave transgingival morphology in order to improve the soft tissue stability was not supported by this review.

The effect of the type of retention on the biological integration of the implant abutment was also explored. The cemented restorations have been associated with biological complications due to the marginal fit of the crown and the excess cement management [80]. Kraus et al. [57] found no statistically significant difference between the two restorative types after 3 years; the cement retained restorations were associated with two catastrophic failures though. The statistical significance of the findings could have been influenced by the small sample size and the high drop-out rate. On the contrary Amorfini et al. [73] found that the frequency of biological complications for zirconia abutments was similar for both retention types. Probably, the equigingival delineation of the margin of the CAD/CAM abutments and hence the easy removal of cement excess, prevented the development of biological complications.

The influence of abutment customization on the biological outcomes was assessed by Wittneben et al. [59] and no significant difference was noted. Still, it has been argued that in cases where a cement retained restoration is considered, the abutment customization seems to be preferable as it enables the margin be placed at the appropriate position.

The modern concept of submucosally veneered zirconia abutments was also investigated in this review, although only one clinical trial [50] was available from 
which to extract the data. After 5 years, the probing depths around the veneered abutments were significantly higher than around the conventional ones. The veneering of zirconia has been associated with surface roughness increase [81], favoring plaque accumulation and subsequent periodontal inflammation. Notably, although the probing depths were increased, the marginal bone levels were not influenced. More randomized trials with larger sample sizes and a longer follow-up period are needed to assess the association of the veneering technique with possible biological effects.

Notably, in a recent systematic review [82] has shown that the different types of implant-abutment interface also affect the mechanical and biological outcome of single-tooth implants in the esthetic area. More specifically the Morse Taper design performed better for marginal bone loss, success, and survival while internal hexagon had the best PES/WES score. This study [82] as well as the current systematic review highlights the need for more robust results from well-designed and executed randomized controlled clinical studies.

\section{Conclusions}

The following conclusions can be drawn from this systematic review:

- Abutment failure, due to fracture, was associated with ceramic abutments and a mean rate was calculated at $4.26 \%$.

- Fracture of the ceramic abutment was more common in the neck area of the internally connected one-piece abutments or in the weakened area due to over-preparation of prefabricated abutments.

- The assumption that ceramic abutments placed on narrow implants are more prone to fractures, was not supported.

- The most common mechanical complication was abutment screw loosening; however, this was considered a minor complication.

- Titanium abutments caused significantly more discoloration to the soft tissues than ceramic abutments, while hueing (gold or pink) slightly improved their color performance.

- Gold or gold hued abutments performed almost like zirconia abutments.

- Limited correlation was noted between soft tissue thickness and color difference.

- Submucosal veneering sometimes seemed to improve the color match of zirconia abutments; however, the translucency and color of the veneering material seemed to influence the outcome. Nevertheless, more randomized trials are needed to assess the esthetic value of this modification and to assess its biological impact, which at this point raised some concerns.

- Similar biological complications were noted for metallic and ceramic materials.

- The type of restoration retention did not appear to significantly affect the biological outcome; however, as screw retained restorations provide more retrievability, they might be a better choice when possible.

\section{Abbreviations}

CAD/CAM: Computer-aided design and computer-aided manufacturing; PRIS MA: Preferred Reporting Items for Systematic Reviews and Meta-Analyses; PROSPERO: International Prospective Register of Systematic Reviews; PICO: Participants/intervention/comparison/outcomes tool;

RCTs: Randomized controlled trials; CENTRAL: Cochrane Central Register of Controlled Trials; MeSh: Medical Subject Headings; ROB 2: Cochrane Risk of Bias tool; No_ patients: Number of patients; No_ abutments: Number of abutments; Zr: Zirconia; Ti: Titanium; PFM: Porcelain fused to metal; N/A: Not applicable or not available; USPHS: United States Public Health Service criteria; SR: Screw retained restoration; CR: Cemented restoration; t: Test; c: Control; B: Baseline; M: Month; Y: Year; PES: Pink esthetic score; WES: White esthetic score; ICAI: Implant crown esthetic index; CIS: Copenhagen index score; PI: Papilla index; VAS: Visual analog scale; KMt: Width of the buccal keratinized mucosa (gingiva) at the adjacent teeth; CLt: Distance between the mid-facial gingival margin and the incisal edge of adjacent teeth; KMi: Width of the buccal keratinized mucosa at the implant site; Cli: Distance between the mid-facial gingival margin and the incisal edge of implant crown; PH: Papilla height; Cl: Crown insertion; $\Delta \mathrm{E}$ : Color difference; G: Gold; P: Pink; W: White

\section{Acknowledgements}

Not applicable.

\section{Authors' contributions}

DT: conception, data acquisition, provision and management of study literature resources, synthesis, visualization, interpretation, and drafted the manuscript. ON: had oversight of the study planning and execution, and to the design, data acquisition, synthesis, interpretation, and drafted the manuscript. SMB, SB: conception, design, and critically revised the manuscript. All authors gave their final approval and agreed to be accountable for all aspects of the work. The authors read and approved the final manuscript.

Funding

Not applicable

Availability of data and materials Not applicable

\section{Declarations}

Ethics approval and consent to participate Not applicable

\section{Consent for publication}

Not applicable

\section{Competing interests}

Dimitra Totou, Olga Naka, Shamir B. Mehta, and Subir Banerji declare that they have no competing interests.

Received: 31 March 2021 Accepted: 16 June 2021

Published online: 08 September 2021

\section{References}

1. Jung RE, Zembic A, Pjetursson BE, Zwahlen M, Thoma DS. Systematic review of the survival rate and the incidence of biological, technical, and aesthetic complications of single crowns on implants reported in longitudinal studies 
with a mean follow-up of 5 years. Clin Oral Implants Res. 2012;23:2-21. https://doi.org/10.1111/j.1600-0501.2012.02547.x.

2. Belser UC, Schmid B, Higginbottom F, Buser D. Outcome analysis of implant restorations located in the anterior maxilla: a review of the recent literature. Int J Oral Maxillofac Implants. 2004;19(Suppl):30-42.

3. Papaspyridakos P, Chen CJ, Singh M, Weber HP, Gallucci GO. Success criteria in implant dentistry: a systematic review. J Dent Res. 2012;91(3):242-8. https://doi.org/10.1177/0022034511431252.

4. Cosyn J, Thoma DS, Hämmerle CH, De Bruyn H. Esthetic assessments in implant dentistry: objective and subjective criteria for clinicians and patients. Periodontol 2000. 2017;73(1):193-202. https://doi.org/10.1111/prd.12163.

5. Sailer I, Zembic A, Jung RE, Hämmerle CH, Mattiola A. Single-tooth implant reconstructions: esthetic factors influencing the decision between titanium and zirconia abutments in anterior regions. Eur J Esthet Dent. 2007;2(3):296310.

6. Pjetursson BE, Sailer I, Zwahlen M, Hämmerle CH. A systematic review of the survival and complication rates of all-ceramic and metal-ceramic reconstructions after an observation period of at least 3 years. Part I: Single crowns. Clin Oral Implants Res. 2007;18(Suppl 3):73-85. https://doi.org/1 0.1111/j.1600-0501.2007.01467.x.

7. Sailer I, Philipp A, Zembic A, Pjetursson BE, Hämmerle CHF, Zwahlen M. A systematic review of the performance of ceramic and metal implant abutments supporting fixed implant reconstructions. Clin Oral Implants Res. 2009;20(Suppl 4):4-31. https://doi.org/10.1111/j.1600-0501.2009.01787.x.

8. Zembic A, Kim S, Zwahlen M, Kelly JR. Systematic review of the survival rate and incidence of biologic, technical, and esthetic complications of single implant abutments supporting fixed prostheses. Int J Oral Maxillofac Implants. 2014;29:Suppl:99-116. https://doi.org/10.11607/jomi.2014suppl. g2.2.

9. Jung RE, Pjetursson BE, Glauser R, Zembic A, Zwahlen M, Lang NP. A systematic review of the 5 -year survival and complication rates of implantsupported single crowns. Clin Oral Implants Res. 2008;19(2):119-30. https:// doi.org/10.1111/j.1600-0501.2007.01453.x.

10. Park SE, Da Silva JD, Weber HP, Ishikawa-Nagai S. Optical phenomenon of peri-implant soft tissue. Part I. Spectrophotometric assessment of natural tooth gingiva and peri-implant mucosa. Clin Oral Implants Res. 2007:18(5): 569-74. https://doi.org/10.1111/j.1600-0501.2007.01391.x.

11. Ishikawa-Nagai S, Da Silva JD, Weber HP, Park SE. Optical phenomenon of peri-implant soft tissue. Part II. Preferred implant neck color to improve soft tissue esthetics. Clin Oral Implants Res. 2007;18(5):575-80. https://doi.org/1 0.1111/j.1600-0501.2007.01390.x

12. Jung RE, Sailer I, Hämmerle CH, Attin T, Schmidlin P. In vitro color changes of soft tissues caused by restorative materials. Int J Periodontics Restorative Dent. 2007:27(3):251-7.

13. Jung RE, Holderegger C, Sailer I, Khraisat A, Suter A, Hämmerle CH. The effect of all-ceramic and porcelain-fused-to-metal restorations on marginal peri-implant soft tissue color: a randomized controlled clinical trial. Int J Periodontics Restorative Dent. 2008;28(4):357-65.

14. Henriksson $\mathrm{K}$, Jemt T. Evaluation of custom-made procera ceramic abutments for single-implant tooth replacement: a prospective 1-year follow-up study. Int J Prosthodont. 2003;16(6):626-30.

15. Andersson B, Taylor A, Lang BR, Scheller H, Scharer P, Sorensen JA, et al. Alumina ceramic implant abutments used for single-tooth replacement: a prospective 1- to 3-year multicenter study. Int J Prosthodont. 2001;14(5): 432-8.

16. Hisbergues $M$, Vendeville $S$, Vendeville P. Zirconia: established facts and perspectives for a biomaterial in dental implantology. J Biomed Mater Res B Appl Biomater. 2009;88(2):519-29. https://doi.org/10.1002/jbm.b.31147.

17. Scarano A, Piattelli M, Caputi S, Favero GA, Piattelli A. Bacterial adhesion on commercially pure titanium and zirconium oxide disks: an in vivo human study. J Periodontol. 2004;75(2):292-6. https://doi.org/10.1902/jop.2004.75.2.292.

18. Degidi M, Artese L, Scarano A, Perrotti V, Gehrke P, Piattelli A. Inflammatory infiltrate, microvessel density, nitric oxide synthase expression, vascular endothelial growth factor expression, and proliferative activity in periimplant soft tissues around titanium and zirconium oxide healing caps. J Periodontol. 2006;77(1):73-80. https://doi.org/10.1902/jop.2006.77.1.73.

19. Nakamura K, Kanno T, Milleding P, Ortengren U. Zirconia as a dental implant abutment material: a systematic review. Int J Prosthodont. 2010;23(4):299-309.

20. Foong JK, Judge RB, Palamara JE, Swain MV. Fracture resistance of titanium and zirconia abutments: an in vitro study. J Prosthet Dent. 2013;109(5):30412. https://doi.org/10.1016/S0022-3913(13)60306-6.
21. Leutert CR, Stawarczyk B, Truninger TC, Hämmerle CH, Sailer I. Bending moments and types of failure of zirconia and titanium abutments with internal implant-abutment connections: a laboratory study. Int J Oral Maxillofac Implants. 2012;27(3):505-12.

22. Bressan E, Paniz G, Lops D, Corazza B, Romeo E, Favero G. Influence of abutment material on the gingival color of implant-supported all-ceramic restorations: a prospective multicenter study. Clin Oral Implants Res. 2011; 22(6):631-7. https://doi.org/10.1111/j.1600-0501.2010.02008.x.

23. Büchi DL, Sailer I, Fehmer V, Hämmerle CH, Thoma DS. All-ceramic singletooth implant reconstructions using modified zirconia abutments: a prospective randomized controlled clinical trial of the effect of pink veneering ceramic on the esthetic outcomes. Int J Periodontics Restorative Dent. 2014;34(1):29-37. https://doi.org/10.11607/prd.1870.

24. Happe A, Schulte-Mattle V, Fickl S, Naumann M, Zoller JE, Rothamel D. Spectrophotometric assessment of peri-implant mucosa after restoration with zirconia abutments veneered with fluorescent ceramic: a controlled, retrospective clinical study. Clin Oral Implants Res. 2013;24:28-33. https:// doi.org/10.1111/j.1600-0501.2011.02361.x.

25. Cao Y, Yu C, Wu Y, Li L, Li C. Long-term survival and peri-implant health of titanium implants with zirconia abutments: a systematic review and metaanalysis. J Prosthodont. 2019;28(8):883-92. https:/doi.org/10.1111/jopr.13097.

26. Naveau A, Rignon-Bret C, Wulfman C. Zirconia abutments in the anterior region: a systematic review of mechanical and esthetic outcomes. J Prosthet Dent. 2019;121(5):775-781.e1. https://doi.org/10.1016/j.prosdent.201 8.08.005.

27. Linkevicius $T$, Vaitelis J. The effect of zirconia or titanium as abutment material on soft peri-implant tissues: a systematic review and meta-analysis. Clin Oral Implants Res. 2015;26(Suppl 11):139-47. https://doi.org/10.1111/ clr.12631.

28. de Medeiros RA, Vechiato-Filho AJ, Pellizzer EP, Mazaro JV, dos Santos DM, Goiato MC. Analysis of the peri-implant soft tissues in contact with zirconia abutments: an evidence-based literature review. J Contemp Dent Pract. 2013;14(3):567-72. https://doi.org/10.5005/jp-journals-10024-1364.

29. Bidra AS, Rungruanganunt P. Clinical outcomes of implant abutments in the anterior region: a systematic review. J Esthet Restor Dent. 2013;25(3):159-76. https://doi.org/10.1111/jerd.12031.

30. Moher D, Liberati A, Tetzlaff J, Altman DG. PRISMA Group, Preferred reporting items for systematic reviews and meta-analyses: the PRISMA statement. Plos Med. 2009;6(7):e1000097. https://doi.org/10.1371/journal. pmed.1000097.

31. Sterne JAC, Savović J, Page MJ, Elbers RG, Blencowe NS, Boutron I, et al. RoB 2: a revised tool for assessing risk of bias in randomised trials. BMJ. 2019;366: 14898. https://doi.org/10.1136/bmj.14898.

32. Zembic A, Sailer I, Jung RE, Hämmerle CH. Randomized-controlled clinical trial of customized zirconia and titanium implant abutments for single-tooth implants in canine and posterior regions: 3 -year results. Clin Oral Implants Res. 2009;20(8):802-8. https://doi.org/10.1111/j.1600-0501.2009.01717.x.

33. Sailer I, Zembic A, Jung RE, Siegenthaler D, Holderegger C, Hämmerle $\mathrm{CH}$. Randomized controlled clinical trial of customized zirconia and titanium implant abutments for canine and posterior single-tooth implant reconstructions: preliminary results at 1 year of function. Clin Oral Implants Res. 2009;20(3):219-25. https://doi.org/10.1111/j.16000501.2008.01636.x.

34. Zembic A, Bösch A, Jung RE, Hämmerle CH, Sailer I. Five-year results of a randomized controlled clinical trial comparing zirconia and titanium abutments supporting single-implant crowns in canine and posterior regions. Clin Oral Implants Res. 2013;24(4):384-90. https://doi.org/10.1111/clr.12044.

35. Bösch A, Jung RE, Sailer I, Goran B, Hämmerle CH, Thoma DS. Single-tooth replacement using dental implants supporting all-ceramic and metal-based reconstructions: results at 18 months of loading. Int J Periodontics Restorative Dent. 2018;38(2):173-9. https://doi.org/10.11607/prd.2846.

36. van Brakel R, Meijer GJ, Verhoeven JW, Jansen J, de Putter C, Cune MS. Soft tissue response to zirconia and titanium implant abutments: an in vivo within-subject comparison. J Clin Periodontol. 2012;39(10):995-1001. https:// doi.org/10.1111/j.1600-051X.2012.01931.X.

37. den Hartog L, Raghoebar GM, Slater JJ, Stellingsma K, Vissink A, Meijer HJ. Single-tooth implants with different neck designs: a randomized clinical trial evaluating the aesthetic outcome. Clin Implant Dent Relat Res. 2013;15(3): 311-21. https://doi.org/10.1111/j.1708-8208.2011.00372.x.

38. Rieder D, Eggert J, Krafft T, Weber HP, Wichmann MG, Heckmann SM. Impact of placement and restoration timing on single-implant esthetic 
outcome - a randomized clinical trial. Clin Oral Implants Res. 2016;27(2):e806. https://doi.org/10.1111/clr.12539.

39. Furze D, Byrne A, Donos N, Mardas N. Clinical and esthetic outcomes of single-tooth implants in the anterior maxilla. Quintessence Int. 2012;43(2): $127-34$

40. Montero J, Manzano G, Beltran D, Lynch CD, Suarez-Garcia M, CastilloOyague R. Clinical evaluation of the incidence of prosthetic complications in implant crowns constructed with UCLA castable abutments. A cohort follow-up study. J Dent. 2012;40(12):1081-9. https://doi.org/10.1016/j.jdent.2 012.09.001.

41. Schwarz S, Schroder C, Hassel A, Bomicke W, Rammelsberg P. Survival and chipping of zirconia-based and metal-ceramic implant-supported single crowns. Clin Implant Dent Relat Res. 2012;14(Suppl 1):e119-25. https://doi. org/10.1111/j.1708-8208.2011.00388.x.

42. Hosseini M, Worsaae N, Schiodt M, Gotfredsen K. A 3-year prospective study of implant-supported, single-tooth restorations of all-ceramic and metalceramic materials in patients with tooth agenesis. Clin Oral Implants Res. 2013;24(10):1078-87. https://doi.org/10.1111/j.1600-0501.2012.02514.x.

43. Fenner $\mathrm{N}$, Hämmerle $\mathrm{CH}$, Sailer I, Jung RE. Long-term clinical, technical, and esthetic outcomes of all-ceramic vs. titanium abutments on implant supporting single-tooth reconstructions after at least 5 years. Clin Oral Implants Res. 2016;27(6):716-23. https://doi.org/10.1111/clr.12654.

44. Kim A, Campbell SD, Viana MA, Knoernschild KL. Abutment material effect on peri-implant soft tissue color and perceived esthetics. J Prosthodont. 2016;25(8):634-40. https://doi.org/10.1111/jopr.12360.

45. Peng M, Zhao W, Hosseini M, Zhou W, Xiao T, Chuan J. Influence of restorative materials on color of implant-supported single crowns in esthetic zone: a spectrophotometric evaluation. Biomed Res Int. 2017;2017: 5034358-7. https://doi.org/10.1155/2017/5034358.

46. Asgeirsson AG, Sailer I, Gamper F, Jung RE, Hämmerle CH, Thoma DS. Veneered zirconia abutments cemented on non-original titanium bases: 1 year results of a prospective case series. Clin Oral Implants Res. 2019;30(8): 735-44. https://doi.org/10.1111/clr.13457.

47. Thoma DS, Brandenberg F, Fehmer V, Büchi DL, Hämmerle CH, Sailer I. Randomized controlled clinical trial of all-ceramic single tooth implant reconstructions using modified zirconia abutments: radiographic and prosthetic results at 1 year of loading. Clin Implant Dent Relat Res. 2016; 18(3):462-72. https://doi.org/10.1111/cid.12333.

48. Brandenberg FD, Sailer I, Fehmer V, Büchi DL, Hämmerle CH, Thoma DS. Randomized controlled clinical pilot study of all-ceramic single-tooth implant reconstructions: clinical and microbiological outcomes at one year of loading. Clin Oral Implants Res. 2017;28(4):406-13. https://doi.org/1 $0.1111 / \mathrm{clr} .12813$

49. Eisner B, Naenni N, Hüsler J, Hämmerle CH, Thoma DS, Sailer I. Three-year results of a randomized controlled clinical trial using submucosally veneered and unveneered zirconia abutments supporting all-ceramic single-implant crowns. Int J Periodontics Restorative Dent. 2018;38(5):64552. https://doi.org/10.11607/prd.3669.

50. Laass A, Sailer I, Hüsler J, Hämmerle CH, Thoma DS. Randomized controlled clinical trial of all-ceramic single-tooth implant reconstructions using modified zirconia abutments: results at 5 years after loading. Int $J$ Periodontics Restorative Dent. 2019;39(1):17-27. https://doi.org/10.11607/ prd.3792.

51. Gallucci GO, Grütter L, Nedir R, Bischof M, Belser UC. Esthetic outcomes with porcelain-fused-to-ceramic and all-ceramic single-implant crowns: a randomized clinical trial. Clin Oral Implants Res. 2011;22(1):62-9. https://doi. org/10.1111/j.1600-0501.2010.01997.x.

52. Gallucci GO, Grütter L, Chuang S, Belser UC. Dimensional changes of periimplant soft tissue over 2 years with single-implant crowns in the anterior maxilla. J Clin Periodontol. 2011;38(3):293-9. https://doi.org/10.1111/j.1600051X.2010.01686.X

53. Heierle L, Wolleb K, Hämmerle CH, Wiedemeier DB, Sailer I, Thoma DS Randomized controlled clinical trial comparing cemented versus screwretained single crowns on customized zirconia abutments: 3 -year results. Int J Prosthodont. 2019;32(2):174-6. https://doi.org/10.11607/ijp.6080.

54. Thoma DS, Wolleb K, Bienz SP, Wiedemeier D, Hämmerle CH, Sailer I. Early histological, microbiological, radiological, and clinical response to cemented and screw-retained all-ceramic single crowns. Clin Oral Implants Res. 2018; 29(10):996-1006. https://doi.org/10.1111/clr.13366.

55. Thoma DS, Brandenberg F, Fehmer V, Knechtle N, Hämmerle CH, Sailer I. The esthetic effect of veneered zirconia abutments for single-tooth implant reconstructions: a randomized controlled clinical trial. Clin Implant Dent Relat Res. 2016;18(6):1210-7. https://doi.org/10.1111/cid.12388.

56. Thoma DS, Sailer I, Mühlemann S, Gil A, Jung RE, Hämmerle CH. Randomized controlled clinical study of veneered zirconia abutments for single implant crowns: clinical, histological, and microbiological outcomes. Clin Implant Dent Relat Res. 2018;20(6):988-96. https://doi.org/10.1111/ cid.12674.

57. Kraus RD, Epprecht A, Hämmerle CH, Sailer I, Thoma DS. Cemented vs screw-retained zirconia-based single implant reconstructions: a 3-year prospective randomized controlled clinical trial. Clin Implant Dent Relat Res. 2019;21(4):578-85. https://doi.org/10.1111/cid.12735.

58. Wittneben JG, Gavric J, Belser UC, Bornstein MM, Joda T, Chappuis V, et al. Esthetic and clinical performance of implant-supported all-ceramic crowns made with prefabricated or CAD/CAM zirconia abutments: a randomized, multicenter clinical trial. J Dent Res. 2017;96(2):163-70. https://doi.org/10.11 $77 / 0022034516681767$

59. Wittneben JG, Gavric J, Sailer I, Buser D, Wismeijer D. Clinical and esthetic outcomes of two different prosthetic workflows for implant-supported allceramic single crowns - 3 year results of a randomized multicenter clinical trial. Clin Oral Impl Res. 2020;31(5):495-505. https://doi.org/10.1111/clr.13586.

60. Patil R, den Hartog L, van Heereveld C, Jagdale A, Dilbaghi A, Cune M. Comparison of two different abutment designs on marginal bone loss and soft tissue development. Int J Oral Maxillofac Implants. 2014;29(3):675-81. https://doi.org/10.11607/jomi.3363.

61. Patil R, den Hartog L, Dilbaghi A, de Jong B, Kerdijk W, Cune MS. Papillary fill response in single-tooth implants using abutments of different geometry. Clin Oral Implants Res. 2016;27(12):1506-10. https://doi.org/1 $0.1111 / \mathrm{clr} .12594$

62. Patil R, Gresnigt MM, Mahesh K, Dilbaghi A, Cune MS. Esthetic evaluation of anterior single-tooth implants with different abutment designs-patients' satisfaction compared to dentists' observations. J Prosthodont. 2017;26(5): 395-8. https://doi.org/10.1111/jopr.12423.

63. Gil MS, Ishikawa-Nagai S, Elani HW, Da Silva JD, Kim DM, Tarnow D, et al. A prospective clinical trial to assess the optical efficacy of pink neck implants and pink abutments on soft tissue esthetics. J Esthet Restor Dent. 2017; 29(6):409-15. https://doi.org/10.1111/jerd.12309.

64. Gil MS, Ishikawa-Nagai S, Elani HW, Da Silva JD, Kim DM, Tarnow D, et al. Comparison of the color appearance of peri-implant soft tissue with natural gingiva using anodized pink-neck implants and pink abutments: a prospective clinical trial. Int J Oral Maxillofac Implants. 2019;34(3):752-8. https://doi.org/10.11607/jomi.6318.

65. Bittner N, Schulze-Spate U, Cleber S, Da Silva JD, Kim DM, Tarnow D, et al. Comparison of peri-implant soft tissue color with the use of pink-neck vs gray implants and abutments based on soft tissue thickness: a 6-month follow-up study. Int J Prosthodont. 2020;33(1):29-38. https://doi.org/10.11 607/ijp.6205.

66. Hosseini M, Worsaae N, Schiodt M, Gotfredsen K. A 1-year randomised controlled trial comparing zirconia versus metal-ceramic implant supported single-tooth restorations. Eur J Oral Implantol. 2011;4(4):347-61.

67. Carrillo de Albornoz A, Vignoletti F, Ferrantino L, Cardenas E, De Sanctis M, Sanz M. A randomized trial on the aesthetic outcomes of implantsupported restorations with zirconia or titanium abutments. J Clin Periodontol. 2014;41(12):1161-9. https://doi.org/10.1111/jcpe.12312.

68. Baldini N, D'Elia C, Clementini M, Carrillo de Albornoz A, Sanz M, De Sanctis M. Esthetic outcomes of single-tooth implant-supported restorations using metal-ceramic restorations with zirconia or titanium abutments: a randomized controlled clinical study. Int J Periodontics Restorative Dent 2016;36(4):e59-66. https://doi.org/10.11607/prd.2599.

69. Paolantoni G, Marenzi G, Blasi A, Mignogna J, Sammartino G. Findings of a four-year randomized controlled clinical trial comparing two-piece and onepiece zirconia abutments supporting single prosthetic restorations in maxillary anterior region. Biomed Res Int. 2016;2016:8767845-6. https://doi. org/10.1155/2016/8767845

70. Lops D, Stellini E, Sbricoli L, Cea N, Romeo E, Bressan E. Influence of abutment material on peri-implant soft tissues in anterior areas with thin gingival biotype: a multicentric prospective study. Clin Oral Implants Res. 2017;28(10):1263-8. https://doi.org/10.1111/clr.12952.

71. Martinez-Rus F, Prieto M, Salido MP, Madrigal C, Ozcan M, Pradies G. A Clinical study assessing the influence of anodized titanium and zirconium dioxide abutments and peri-implant soft tissue thickness on the optical outcome of implant-supported lithium disilicate single 
crowns. Int J Oral Maxillofac Implants. 2017;32(1):156-63. https://doi. org/10.11607/jomi.5258.

72. Thoma DS, Gamper FB, Sapata VM, Voce G, Hämmerle CH, Sailer I. Spectrophotometric analysis of fluorescent zirconia abutments compared to "conventional" zirconia abutments: a within subject controlled clinical trial. Clin Implant Dent Relat Res. 2017;19(4):760-6. https://doi.org/10.1111/ cid.12488.

73. Amorfini L, Storelli S, Mosca D, Scanferla M, Romeo E. Comparison of cemented vs screw-retained, customized computer-aided design/computerassisted manufacture zirconia abutments for esthetically located singletooth implants: a 10-year randomized prospective study. Int J Prosthodont. 2018;31(4):359-66. https://doi.org/10.11607/ijp.5305.

74. Koutouzis T, Adeinat B, Ali A. The influence of abutment macro-design on clinical and radiographic peri-implant tissue changes for guided, placed, and restored implants: a 1-year randomized controlled trial. Clin Oral Implants Res. 2019;30(9):882-91. https://doi.org/10.1111/clr.13493.

75. Johnston WM, Kao EC. Assessment of appearance match by visual observation and clinical colorimetry. J Dent Res. 1989;68(5):819-22. https:// doi.org/10.1177/00220345890680051301.

76. Gracis S, Michalakis K, Vigolo P, Vult von Steyern P, Zwahlen M, Sailer I. Internal vs. external connections for abutments/reconstructions: a systematic review. Clin Oral Implants Res. 2012;23(Suppl 6):202-16. https:// doi.org/10.1111/j.1600-0501.2012.02556.x.

77. Truninger TC, Stawarczyk B, Leutert CR, Sailer TR, Hämmerle CH, Sailer I. Bending moments of zirconia and titanium abutments with internal and external implant-abutment connections after aging and chewing simulation. Clin Oral Implants Res. 2012;23(1):12-8. https://doi.org/10.1111/ j.1600-0501.2010.02141.x.

78. Mühlemann S, Truninger TC, Stawarczyk B, Hämmerle CH, Sailer I. Bending moments of zirconia and titanium implant abutments supporting allceramic crowns after aging. Clin Oral Implants Res. 2014;25(1):74-81. https:// doi.org/10.1111/clr.12192.

79. Hjerppe J, Narhi T, Fröberg K, Vallittu P, Lassila L. Effect of shading the zirconia framework on biaxial strength and surface microhardness. Acta Odontol Scand. 2008;66(5):262-7. https://doi.org/10.1080/0001635080224 7123 .

80. Sailer I, Mühlemann S, Zwahlen M, Hämmerle CH, Schneider D. Cemented and screw-retained implant reconstructions: a systematic review of the survival and complication rates. Clin Oral Implants Res. 2012;23(Suppl 6): 163-201. https://doi.org/10.1111/j.1600-0501.2012.02538.x.

81. Mustafa K, Wennerberg A, Arvidson K, Messelt EB, Haag P, Karlsson S. Influence of modifying and veneering the surface of ceramic abutments on cellular attachment and proliferation. Clin Oral Implants Res. 2008;19(11): 1178-87. https://doi.org/10.1111/j.1600-0501.2008.01560.x.

82. Vetromilla BM, Brondani LP, Pereira-Cenci T, Bergoli CD. Ifluence of different implant-abutment connection designs on the mechanical and biological behavior of single-tooth implants in the maxillary esthetic zone: a systematic review. J Prosthet Dent. 2019;121(3):398-403. https://doi.org/10.1 016/j.prosdent.2018.05.007.

\section{Publisher's Note}

Springer Nature remains neutral with regard to jurisdictional claims in published maps and institutional affiliations.

\section{Submit your manuscript to a SpringerOpen ${ }^{\circ}$ journal and benefit from:}

- Convenient online submission

- Rigorous peer review

- Open access: articles freely available online

- High visibility within the field

- Retaining the copyright to your article

Submit your next manuscript at $\boldsymbol{\nabla}$ springeropen.com 